\title{
Conservation Agriculture-An Ideal Resource Management Strategy for Sustainable Oilseed Production in India
}

ISSN: 2637-7659

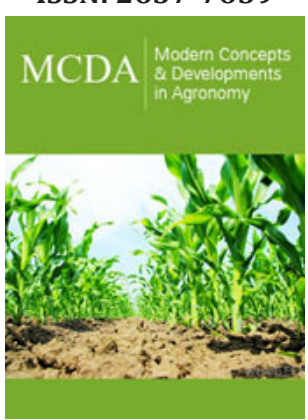

*Corresponding author: Suresh G, Crop Production Division, Indian institute of Oilseeds Research, Hyderabad, India

Submission: 悳 February 09, 2021

Published:

Volume 8 - Issue 1

How to cite this article: Suresh $\mathrm{G}^{*}$, Sudhakara Babu SN, A Aziz Qureshi. Conservation Agriculture-An Ideal Resource Management Strategy for Sustainable Oilseed Production in India. Mod Concep Dev Agrono. 8(1). MCDA. 000678. 2021. DOI: 10.31031/MCDA.2021.08.000678

Copyright@ Suresh G This article is distributed under the terms of the Creative Commons Attribution 4.0 International License, which permits unrestricted use and redistribution provided that the original author and source are credited.

\section{Suresh G*, Sudhakara Babu SN and A Aziz Qureshi}

ICAR-Indian Institute of Oilseeds Research, Rajendranagar, Hyderabad-500030, Telangana State, India

\begin{abstract}
Low productivity of oilseed crops in India is due to their majority cultivation under rainfed condition in low soil fertility and prone to erosion. Conservation agricultural practices viz., reduced tillage, crop residue cover, crop rotation play an important role in initiating changes in physical, chemical and biological properties which in turn enrich carbon pools and improve the crop yields sustainably. Resource Conservation Technologies in Rice-wheat based cropping systems in Indo-Gangetic plains are huge success and gaining popularity. Conservation agriculture can be seen as a new way forward for conserving resources and enhancing oilseed productivity to achieve goals of sustainable agriculture and nutritional security in India. However, it demands development of location specific CA technologies and combination of institutional and policy support.
\end{abstract}

Keywords: Oilseed crops; Reduced tillage; Resource conservation; Soil fertility

Abbreviations: CA: Conservation Agriculture; ICAR: Indian Council of Agricultural Research; SAT: SemiArid Tropics; SDG: Sustainable Development Goals

\section{Introduction}

Conservation Agriculture (CA) has been established as a resource-saving agricultural production system to achieve production intensification and high yields along with enhancing the natural resource base through the positive interplay of related principles of minimum soil disturbance, crop residue cover and crop associations and cover crop [1,2].

In India, vegetable oils are critical for nutrition, energy and economy of the country and in global commodity supplies. In terms of acreage, production and economic value, oilseed crops are second only to food grains. But self-reliance in edible oils is not in sight and the country imports almost half of its edible oil requirements. With its rich agro-ecological diversity, India is ideally suited for growing all the major annual oilseed crops. Among the nine oilseed crops grown in the country, seven are of edible oils (soybean, groundnut, rapeseed-mustard, sunflower, sesame, safflower and niger) and two are of non-edible industrial oils (castor and linseed).Low and unstable yields of most oilseed crops, and uncertainty in returns to investment, is due to their majority cultivation under rainfed conditions in poor soils with low organic carbon, high climate risk production environments leading to the situation of unsustainability and wide demand-supply gap.

Low-cost technologies with high impact on productivity and emphasis on ecofriendliness, high input use efficiency such as CA is the new way forward for enhancing the oilseed productivity and nutritional security on a sustainable basis. Different oilseed crops are grown under unique and specific agro-ecologies of soil, season and cropping systems that require specific packages of CA practices. The present review focusses on global status of CA, its benefits and the need for adopting CA practices for enhancing the oilseed productivity on a sustainable basis in the changing climatic scenario. 


\section{Status of CA}

This technology has been widely adopted globally on more than $157 \mathrm{M}$ ha in over 50 countries, largely in rainfed areas. The major countries are USA, Australia, Canada, Argentina, Brazil, Paraguay, Uruguay and New Zealand. In India, the benefits of CA were proven on zero-till wheat in north-western India, primarily through the efforts of IRRI, CIMMYT and World Bank funded NATP [3]. The spread of CA technologies is growing in the irrigated regions in the Indo-Gangetic plains for rice-wheat cropping systems. Research on Conservation agriculture systems in other major agro-ecoregions like rainfed semi-arid tropics and the arid regions of the mountain agro-ecosystems and shallow soil types is in its infancy and needs intensification.

\section{Benefits of CA}

Agriculture's contribution to the Sustainable Development Goals (SDG) requires climate-smart and profitable farm innovations such as adopting conservation agricultural practices [4]. CA practices on smallholder farming systems with zero-till in combination with crop residue retention and crop rotation/ associations has significantly increased rainfed crop productivity in dry climates of sub-Saharan Africa and South Asia [5]. Burning of crop residues causing pollution, greenhouse gas emission and loss of plant nutrients can be reversed for benefiting, improving soil health and environment through CA practices. Through CA crop residues are retained on soil surface and in combination with reduced tillage, it initiates processes that enrich carbon pools and lead to improved soil quality and resource enhancement [6,7].

\section{Discussion}

Intensive agricultural systems with green revolution technologies (high yielding varieties, fertilizer and agro-chemicals, irrigation, fine tilth, minimal crop rotation, manure and crop residue cover etc) has caused exploitation of natural resources resulting in degradation of natural resources, soil health and environment. Energy requirement has increased many folds resulting in high input costs. CA offers one of the viable options to the farmers for crop diversification overcoming the fatigue of resource management to improve and sustain the productivity.

Conservation agriculture helps in sequestering atmospheric carbon in soil-plant system through favourable agricultural operations and management practices. Conservation tillage along with efficient management of inputs viz. irrigation, fertilizer and pesticides facilitate low erosion, high residue cover and higher microbial activity. Land use change and conventional intensification of agricultural practices are major contributors to global annual emission of $\mathrm{CO}_{2}$. Conservation agriculture and Best Management Practices (BMPs) collectively help to offset part of the emissions due to unscientific agricultural practices and offers ecosystem services.
The research carried out by us at Indian Institute of oilseeds Research under rainfed conditions in shallow Alfisols with about $730 \mathrm{~mm}$ annual rainfall in SAT region for the past few years revealed adopting tillage practices (zero, reduced and conventional system) in castor based cropping systems were at par on castor productivity with marginal increase in organic carbon and soil health. Under such scenario, intercropping with medium duration pigeon pea and castor with peanuts and green gram in additive series offer better utilization of above and below ground moisture and nutrients, with high soil cover through leaf fall as mulch. Under similar agro ecology, double cropping of green gram-zero til relay castor and green gram residue as mulch provided higher productivity, profitability and resource conservation. Similar responses were seen in oilseed crops like groundnut [4] soybean and rapeseed-mustard.

Rapeseed-mustard is a climate resilient oilseed crop which can be grown successfully with residual soil moisture after paddy especially in North-Eastern states of Assam and Manipur. Adopting zero tillage has promise and help in timely sowing (OctoberNovember), conserve soil moisture and requires less water, saves tillage cost and time and the soil is protected from erosion due to the retention of surface residues and reduce organic matter depletion and leading to enhanced productivity. Similarly, in eastern and coastal areas of India, there exists immense potential for productive utilization of rice fallows through promoting oilseed crops like sunflower and sesame crops through CA technology.

\section{Conclusion}

Conservation Agriculture has potential to reverse the process of land degradation and ensure sustainable crop production and to combat the adverse effect of climate change and provides ecosystem services. Adoption of CA principles is more relevant for oilseed crops that are largely cultivated in marginal and sub-marginal lands prone to soil erosion and retain less water resulting in poor productivity. CA can be a new way forward for conserving resources and enhancing oilseed productivity in India. Identification of best bet location specific CA practices/technologies for various rainfed production systems involving oilseed crops is the need of the hour. Under irrigated conditions diversification of major rice-wheat cropping systems in Indo-Gangetic plains by adopting conservation principles with the inclusion of oilseed crops provides large scale sustainability besides increasing oilseed production in the country.

In today's agri-food economic system, farmers cannot undertake such transformative changes on their own. To address the mounting climate crisis, it requires favourable policy support for achieving objectives of SDG and real ecosystem services for adopting CA practices.

\section{References}

1. Abrol IP, Sangar S (2006) Sustaining Indian agriculture-conservation agriculture the way forward. Curr Sci 91(8): 1020-1025. 
2. FAO (2020) Food and Agriculture Organization of the United Nations. Rome, Italy.

3. Sharma AR, Singh PK, Mishra JS (2016) Adoption of conservation agriculture-based technologies in the non-indo gangetic plains of India. $4^{\text {th }}$ International Agronomy Congress, New Delhi, India.

4. Jat ML, Chakraborty D, Ladha JK, Rana DS, Gathala MK, et al. (2020) Conservation agriculture for sustainable intensification in South Asia. Nature Sustainability 3: 336-343.
5. Pittelkow C, Liang X, Linquist B, Groenigen KJ, Lee J, et al. (2015) Productivity limits and potentials of the principles of conservation agriculture. Nature 517: 365-368.

6. Jain NK, Jat RS, Meena HN, Chakraborty K (2018) Productivity, nutrient and soil enzymes influenced with conservation agriculture practices in peanut. Agronomy Journal 110(3): 1165-1172.

7. Lal R (2013) Climate-resilient agriculture and soil organic carbon. Ind J of Agron 58(4): 440-450.

For possible submissions Click below: 